\title{
PENGARUH PEMBERIAN JUS LIDAH BUAYA TERHADAP KADAR GLUKOSA DARAH PUASA PADA WANITA PREDIABETES
}

\author{
Putri Sukma Pertiwi, Hesti Murwani ${ }^{*}$ \\ Program Studi Ilmu Gizi Fakultas Kedokteran Universitas Diponegoro \\ Jl.Dr.Sutomo No.14, Semarang, Telp (024) 8453708, Email : gizifk@undip.ac.id
}

\begin{abstract}
Background: Prediabetes is a condition which pioneers of DM. Diet management is the effective method to decrease fasting blood glucose (FBG) level. One of plant that correlates decreasing FBG level is Aloe vera. The purpose of the study was to prove the effects of Aloe vera on FBG level in prediabetes women.

Method: This study was quasi experiment with pre test-post test design. The subjects were people in Tlogosari Kulon Semarang who taken by consecutive sampling. Total subjects were 26 people which was divided in 2 groups. The treatment group was given juice Aloe vera 150 gram per day during 14 days and control group was not given juice Aloe vera. FBG level was measured before and after intervention using spectrofotometri method. During intervention, both of group recorded food intake using food record and food recall. Data was analyzed by Independent sample t-test, Mann Whitney test, and Wilcoxon test.

Result : The decreasing of FBG level in treatment group was $20.38 \pm 14.7$ (18.92\%) $\mathrm{mg} / \mathrm{dl}$ and control group was $0.38 \pm 11.12 \mathrm{mg} / \mathrm{dl}$. Statistic analysis showed that there was significant difference at decreasing of FBG level in treatment group and control group.

Conclusion : There was significant decreasing FBG level $20.38 \mathrm{mg} / \mathrm{dl}$ after given juice Aloe vera 150 gram per day during 14 days.

Key word: Aloe vera, fasting blood glucose, prediabetes
\end{abstract}

Keywords: filter coffee; nonfilter coffee; trygliseride level; sprague dawley rats

\begin{abstract}
ABSTRAK
Latar Belakang : Prediabetes merupakan suatu keadaan yang mendahului timbulnya DM. Pengaturan diet merupakan cara efektif untuk menurunkan kadar glukosa darah puasa (GDP). Salah satu bahan pangan yang dihubungkan dengan penurunan kadar GDP adalah lidah buaya. Penelitian ini bertujuan untuk membuktikan pengaruh lidah buaya terhadap kadar GDP pada wanita prediabetes.

Metode : Penelitian ini merupakan penelitian quasi experiment dengan pre test-post test design. Subjek penelitian adalah warga Kelurahan Tlogosari Kulon Semarang, diambil secara consecutive sampling dengan besar sampel sebanyak 26 orang yang dibagi secara acak dalam 2 kelompok. Kelompok perlakuan diberi jus lidah buaya sebanyak 150 gram/hari selama 14 hari sedangkan kelompok kontrol tidak diberi jus lidah buaya. Kadar GDP diukur sebelum dan setelah intervensi menggunakan metode spektrofotometri. Selama intervensi, asupan makan kedua kelompok diperoleh dengan metode food record dan food recall. Analisis statistik yang digunakan adalah Independent sample t-test, Mann Whitney test, dan Wilcoxon test.

Hasil : Pada kelompok perlakuan terjadi penurunan kadar GDP sebesar 20.38 14.7 (18.92\%) mg/dl sedangkan pada kelompok kontrol $0.38 \pm 11.12 \mathrm{mg} / \mathrm{dl}$. Uji statistik menunjukkan perbedaan penurunan kadar GDP antara kelompok perlakuan dan kelompok kontrol.

Simpulan : Terdapat penurunan secara bermakna kadar GDP sebessar $20.38 \mathrm{mg} / \mathrm{dl}$ setelah pemberian 150 gram jus lidah buaya selama 14 hari.
\end{abstract}

Kata kunci : lidah buaya; kadar glukosa darah puasa; prediabetes

\section{PENDAHULUAN}

Diabetes mellitus (DM) adalah suatu sindroma gangguan metabolisme yang ditandai dengan peningkatan kadar glukosa darah sebagai akibat dari ganguan sekresi insulin, gangguan efektifitas insulin atau keduanya. ${ }^{1}$ Berdasarkan data Kementerian Kesehatan RI tahun 2008, prevalensi penyakit DM di Indonesia sebesar 5,7 $\%$. ${ }^{2}$ Menurut Dinas Kesehatan Kota Semarang prevalensi DM paling tinggi pada tahun 2011 terjadi di wilayah kerja Puskesmas Tlogosari Kulon yaitu terdapat 2.957 kunjungan pasien DM. ${ }^{3}$

Tindakan pencegahan dan penatalaksanaan penyakit DM perlu dilakukan secara dini karena terdapat kecenderungan peningkatan prevalensi kejadian DM dari tahun ke tahun sehingga. Manajemen DM sangat efektif dilakukan pada tahap prediabetes yaitu suatu keadaan yang

${ }^{*}$ Penulis Penanggungjawab 
mendahului timbulnya DM. Prediabetes ditandai dengan kadar glukosa darah puasa antara 100-125 $\mathrm{mg} / \mathrm{dl}^{4}{ }^{4}$ Berdasarkan penelitian yang dilakukan pada 18.956 orang dewasa di Indonesia diketahui bahwa prevalensi prediabetes sebesar $10 \%$. Diketahui bahwa dari $10 \%$ penderita prediabetes, $61.5 \%$ berjenis kelamin wanita, $65.7 \%$ berusia $\geq$ 38 tahun, dan $40.9 \%$ mengalami obesitas sentral. Manajemen DM perlu dilakukan secara dini terutama pada wanita, orang dewasa di atas 30 tahun, dan orang yang memiliki kelebihan berat badan mengingat prevalensi prediabetes pada golongan ini cukup tinggi. ${ }^{5}$ Prediabetes diketahui dapat meningkatkan risiko terjadinya gangguan kardiovaskular sebesar 1,5 kali lebih tinggi dibanding orang sehat. Kondisi prediabetes dapat diperbaiki dengan merubah gaya hidup, menurunkan berat badan, mengatur diet, dan melakukan olahraga secara teratur. ${ }^{4}$

Pengaturan diet merupakan cara efektif untuk menurunkan kadar glukosa darah. Salah satu bahan makanan yang dihubungkan dengan penurunan kadar glukosa darah adalah lidah buaya (Aloe vera, A. vera). A. vera merupakan salah satu bahan pangan yang digunakan sebagai antihiperglikemik. Kandungan aktif antihiperglikemik pada $A$. vera adalah polisakarida acemannan dan glucomannan, glikoprotein, antioksidan, flavonoid, berbagai vitamin dan mineral. $^{6}$

Berdasarkan penelitian yang dilakukan pada tikus, pemberian ektrak lidah buaya dengan pelarut air sebanyak 1 gram/100 gram BB tikus selama 4 minggu dapat menurunkan kadar glukosa darah yaitu dari $266.4 \mathrm{mg} / \mathrm{dl}$ menjadi $139.2 \mathrm{mg} / \mathrm{dl}^{7}$ Jika dosis ini dikonversikan sesuai kebutuhan manusia yang memiliki berat badan $70 \mathrm{~kg}$, diketahui bahwa pemberian ekstrak lidah buaya selama 30 hari sebanyak 56 gram per hari dapat memberikan efek terhadap penurunan kadar glukosa darah secara signifikan. Penelitian ini menggunakan dosis dan durasi intervensi yang berbeda yaitu sebanyak 150 gram selama 14 hari dikarenakan lidah buaya yang diberikan dalam bentuk jus dan durasi yang digunakan lebih singkat.

Penurunan kadar glukosa darah pada tikus putih (Rattus norvegicus) hiperglikemik diduga berasal dari efek antioksidan yaitu dengan mencegah oksidasi glukosa dan menurunkan potensi enzim-enzim yang berperan dalam pemindahan gugus fosfat pada glukosa yang merupakan tahap awal proses glikosilasi. ${ }^{8}$ Pemberian $A$. vera dapat menurunkan kadar glukosa dalam darah dan meningkatkan glikogen dalam hati kemungkinan karena $A$. vera dapat meningkatkan aktivitas sel $\beta$ pankreas dalam menstimulasi biosintesis dan sekresi insulin. ${ }^{8}$

Jus lidah buaya adalah salah satu bentuk olahan lidah buaya yang efektif digunakan sebagai terapi hipoglikemik. Bila dibanding ekstrak lidah buaya, proses pembuatan jus lebih mudah untuk dilakukan. Penelitian mengenai efek hipoglikemik ekstrak lidah buaya telah banyak dilakukan pada tikus hiperglikemik, tetapi belum banyak penelitian mengenai efek jus lidah buaya terhadap kadar glukosa darah pada penderita prediabetes. Oleh karena itu peneliti ingin melakukan penelitian tentang pengaruh pemberian jus lidah buaya (A. vera) terhadap kadar glukosa darah puasa pada wanita prediabetes di wilayah kerja Puskesmas Tlogosari Kulon.

\section{METODE PENELITIAN}

Penelitian dilakukan di wilayah kerja Puskesmas Tlogosari Kulon pada bulan Mei-Juni 2012. Desain penelitian yang digunakan adalah quasi experiment dengan pre test - post test design. Subyek penelitian adalah wanita 40-55 tahun di wilayah kerja Puskesmas Tlogosari Kulon yang diambil secara consecutive sampling. Kriteria inklusi subjek penelitian adalah bersedia menjadi subjek penelitian dengan mengisi informed consent, wanita berusia 40-55 tahun, IMT 23-29.9 $\mathrm{kg} / \mathrm{m} 2$, kadar glukosa darah puasa (GDP) 100-125 $\mathrm{mg} / \mathrm{dl}$, tidak mengkonsumsi obat-obatan yang mengendalikan kadar glukosa darah, dalam keadaan sadar, dapat diajak berkomunikasi, dan tidak dalam keadaan sakit atau dalam perawatan dokter terkait penyakit DM.

Sampel penelitian diperoleh dari 4 posyandu lansia binaan Puskemas Tlogosari Kulon. Sebanyak 182 wanita bersedia diperiksa kadar glukosa darah puasa saat skrining. Namun hanya 26 orang yang memiliki kriteria inklusi menjadi subjek penelitian. Subjek yang terpilih dibagi secara acak dalam 2 kelompok yaitu kelompok kontrol dan kelompok perlakuan. Selama penelitian seluruh subjek yang terpilih mengikuti penelitian sesuai dengan prosedur penelitian sehingga di akhir penelitian diperoleh 26 orang sebagai subyek penelitian, jumlah tersebut telah memenuhi sampel minimal penelitian.

Kelompok perlakuan diberi intervensi jus lidah buaya sebanyak 150 gram selama 14 hari di luar jam makan utama sedangkan kelompok kontrol tidak diberi jus lidah buaya. Kedua kelompok diminta mencatat semua makanan yang dikonsumsi dalam form food record. Selama 
penelitian, peneliti mencatat dan memantau efek pemberian jus lidah buaya yang dirasakan oleh subyek penelitian. Kepatuhan mengkonsumsi jus lidah buaya dipantau dengan formulir daya terima. Pada hari ke-15 dilakukan pengukuran kembali kadar glukosa darah puasa sebagai data akhir.

Data yang dikumpulkan berupa data primer meliputi data umum subjek, data antropometri, data asupan makan, data tingkat kepatuhan, pengukuran antropometri, dan pengukuran kadar glukosa darah puasa. Data yang dikumpulkan melalui wawancara adalah data umum subjek, data asupan makan, dan tingkat kepatuhan. Data yang dikumpulkan melalui pengukuran antropometri adalah data berat badan yang diperoleh melalui penimbangan dengan timbangan digital dan data tinggi badan yang diperoleh melalui pengukuran dengan mikrotoa. Pengukuran kadar glukosa darah puasa dilakukan oleh laboratorium " $\mathrm{S}$ " menggunakan metode spektrofotometri.

Variabel bebas yang digunakan dalam penelitian ini adalah jus lidah buaya. Lidah buaya yang digunakan adalah varietas barbadensis dengan spesifikasi tua (10-12 bulan setelah pembibitan atau 2-4minggu setelahnya pemanenan pertama) dan besar. Lidah buaya diolah dengan cara dikupas, dicuci 5-6 kali, dipotong dadu, ditimbang sebanyak 150 gram, dihaluskan dengan menggunakan blender, ditambah air pandan sebanyak $150 \mathrm{cc}$ lalu ditambahkan pemanis buatan tanpa kalori sebanyak 2 gram/sachet dengan kandungan sorbitol $1.97 \mathrm{mg} /$ sachet, sukralose 9.8 $\mathrm{mg} / \mathrm{sachet}$ (ADI $15 \mathrm{mg} / \mathrm{hari}$ ), asesulfam 8 $\mathrm{mg} / \mathrm{sachet}$ (ADI $15 \mathrm{mg} / \mathrm{hari}$ ), bubuk jagung dan kromium pikolinat. Jus lidah buaya diberikan sekali dalam sehari di luar jam makan utama selama 14 hari. Variabel terikat adalah perubahan kadar GDP. Kadar GDP diukur setelah subjek penelitian berpuasa selama $10 \mathrm{jam}$, diambil pada pembuluh vena di lengan, sebelum dan sesudah intervensi, dengan satuan $\mathrm{mg} / \mathrm{dl}$, yang dilakukan oleh petugas laboratorium "S". Variabel perancu adalah asupan yaitu rerata energi, karbohidrat, protein, lemak dan serat subjek penelitian selama penelitian yang diperoleh dengan metode food recall $3 \times 24$ jam untuk mengetahui asupan sebelum intervensi dan food record selama $14 \times 24$ jam selama intervensi yang diolah menggunakan nutrisurvey.

Data yang diperoleh diolah dengan program komputer. Normalitas data tersebut diuji dengan Shapiro-wilk. Perbedaan kadar glukosa darah pada masing-masing kelompok diuji dengan Wilcoxon. Perbedaan kadar glukosa darah pada kedua kelompok diuji dengan Independent t-test.

\section{HASIL PENELITIAN}

Hasil penelitian menunjukkan bahwa rerata kadar GDP sebelum intervensi pada kelompok perlakuan adalah $110.07 \mathrm{mg} / \mathrm{dl}$ dan $108.00 \mathrm{mg} / \mathrm{dl}$ pada kelompok kontrol. Pemberian jus lidah buaya sebanyak 150 gram per hari selama 14 hari diketahui dapat menurunkan kadar GDP secara bermakna $(p<0.05)$ dan menunjukkan perbedaan perubahan kadar GDP antara kelompok kontrol dan perlakuan $(p<0.05)$. Kadar glukosa darah puasa dipengaruhi oleh banyak faktor yaitu asupan, usia, indeks massa tubuh, aktivitas fisik, dan status menopause. Karakteristik subyek penelitian pada kedua kelompok dapat dilihat pada tabel 1.

Tabel 1. Karakteristik Subyek Penelitian

\begin{tabular}{|c|c|c|c|c|}
\hline \multirow[t]{2}{*}{ Karakteristik Subjek } & \multicolumn{2}{|c|}{ Perlakuan $(n=13)$} & \multicolumn{2}{|c|}{ Kontrol $(n=13)$} \\
\hline & $\mathrm{n}$ & $\%$ & $\mathrm{n}$ & $\%$ \\
\hline \multicolumn{5}{|l|}{ Kelompok usia } \\
\hline 40-44 tahun & 4 & 15.38 & 0 & 0 \\
\hline 45-49 tahun & 5 & 19.23 & 5 & 19.23 \\
\hline 50-55 tahun & 4 & 15.38 & 8 & 30.76 \\
\hline \multicolumn{5}{|l|}{ IMT } \\
\hline $\begin{array}{c}\text { Overweight (23-24,9 } \\
\left.\mathrm{kg} / \mathrm{m}^{2}\right)\end{array}$ & 4 & 15.38 & 3 & 11.53 \\
\hline $\begin{array}{c}\text { Obesitas I }(25-29,9 \\
\left.\mathrm{kg} / \mathrm{m}^{2}\right)\end{array}$ & 9 & 34.61 & 10 & 38.46 \\
\hline \multicolumn{5}{|l|}{ Aktifitas fisik } \\
\hline Ringan & 3 & 11.53 & 2 & 7.69 \\
\hline Sedang & 10 & 38.46 & 11 & 42.30 \\
\hline
\end{tabular}

Status Menstuasi 


$\begin{array}{ccccc}\text { Belum Menopause } & 7 & 26.92 & 3 & 11.53 \\ \text { Menopause } & 6 & 23.07 & 10 & 38.46\end{array}$

Subyek penelitian sebagian besar berada pada kelompok usia 50-55 tahun (46.14\%), indeks massa tubuh (IMT) sebagian besar tergolong obesitas I (73.07\%), tingkat aktifitas fisik tergolong sedang $(80.8 \%)$, dan sebagian besar sudah menopause $(61.53 \%)$.

\section{Keadaan Subyek Penelitian pada awal penelitian}

Keadaan subyek penelitian disajikan untuk mengetahui homogenitas variabel pada kedua kelompok.

Tabel 2. Keadaan Subyek Penelitian pada awal penelitian

\begin{tabular}{llccc}
\hline & Variabel & Perlakuan $(\mathrm{n}=13)$ & Kontrol $(\mathrm{n}=13)$ & $\mathrm{p}$ \\
\hline Usia & median (min-max) & $48(42-55)$ & $54(45-55)$ & 0.029 \\
& & & $\mathrm{~b}_{*}$ \\
IMT & mean $\pm \mathrm{SD}$ & $26.5 \pm 2.5$ & 27.3 & $0.462^{\mathrm{a}}$ \\
$\mathrm{AF}$ & mean $\pm \mathrm{SD}$ & $2307.5 \pm 127.8$ & $2397.7 \pm 168.2$ & $0.137^{\mathrm{a}}$ \\
\hline \multicolumn{2}{l}{ Keterangan: $p^{*}=$ beda bermakna, $a=$ Independent $t$-test, $b=$ Mann Whitney test }
\end{tabular}

Tabel 2 menunjukan tidak ada perbedaan IMT dan aktivitas fisik antara kelompok kontrol dan perlakuan $(p>0.05)$. Namun ada perbedaan umur bermakna antara kedua kelompok $(p<0.05)$.

Asupan Sebelum dan Selama Intervensi
Asupan makan sebelum dan selama intervensi disajikan untuk mengetahui perubahan asupan yang terjadi pada subyek penelitian sebelum dilakukan intervensi. Perbedaan rerata kedua kelompok terlihat pada tabel di bawah ini.

Tabel 3. Asupan Sebelum dan Selama Intervensi

\begin{tabular}{|c|c|c|c|c|}
\hline \multicolumn{2}{|c|}{ Variabel } & Perlakuan $(n=13)$ & Kontrol $(n=13)$ & $\mathrm{p}$ \\
\hline Asupan E pre & mean \pm SD & $1804.3 \pm 245.2$ & $1679 \pm 237.5$ & $0.201^{\mathrm{a}}$ \\
\hline Asupan E post & mean $\pm \mathrm{SD}$ & $1780.6 \pm 185.0$ & $1662.2 \pm 234.7$ & $0.168^{\mathrm{a}}$ \\
\hline Asupan KH pre & mean $\pm S D$ & $234.8 \pm 35.8$ & $240.3 \pm 33$ & $0.685^{\mathrm{a}}$ \\
\hline Asupan $\mathrm{KH}$ post & mean $\pm \mathrm{SD}$ & $238.1 \pm 30.8$ & $238.1 \pm 36.0$ & $0.841^{\mathrm{a}}$ \\
\hline Asupan P pre & mean $\pm \mathrm{SD}$ & $47.2 \pm 9.9$ & $41.8 \pm 9.5$ & $0.167^{\mathrm{a}}$ \\
\hline Asupan P post & mean $\pm \mathrm{SD}$ & $48.1 \pm 8.9$ & $43.3 \pm 7.6$ & $0.137^{\mathrm{a}}$ \\
\hline Asupan L pre & mean $\pm S D$ & $75.9 \pm 13.6$ & $60.9 \pm 10.2$ & $0.004^{\mathrm{a}^{*}}$ \\
\hline Asupan L post & mean $\pm \mathrm{SD}$ & $70.4 \pm 9.6$ & $59.6 \pm 12.3$ & $0.021^{\mathrm{a}^{*}}$ \\
\hline Asupan serat pre & $\begin{array}{l}\text { median }(\min -\max ) \\
\text { mean } \pm \mathrm{SD}\end{array}$ & $11.3 \pm 1.9$ & $12.8(9.1-16.2)$ & $0.153^{\mathrm{b}}$ \\
\hline Asupan serat post & $\begin{array}{l}\text { median }(\min -\max ) \\
\text { mean } \pm \mathrm{SD}\end{array}$ & $11.8 \pm 1.9$ & $12.0(9.7-20.4)$ & $0.390^{\mathrm{b}}$ \\
\hline
\end{tabular}

Keterangan: $p^{*}=$ beda bermakna, $a=$ Independent $t$-test,$b=$ Mann Whitney

Tabel 3 menunjukkan tidak terdapat perbedaan asupan energi, karbohidrat, protein, dan serat antara kedua kelompok pada awal penelitian dan selama penelitian $(p>0.05)$. Namun terdapat perbedaan asupan lemak secara antara kedua kelompok $(p<0.05)$.
Perbedaan Perubahan Asupan Sebelum dan Selama Intervensi

Perbedaan perubahan asupan penelitian pada awal penelitian dan selama intervensi, dapat dilihat pada tabel di bawah ini. 
Tabel 5. Perbedaan Perubahan Asupan Sebelum dan Selama Intervensi

\begin{tabular}{lccc}
\hline \multirow{2}{*}{ Variabel } & Perlakuan $(\mathrm{n}=13)$ & Kontrol $(\mathrm{n}=13)$ & \multirow{2}{*}{$\mathrm{p}$} \\
\cline { 2 - 3 } & Mean $\pm \mathrm{SD}$ & Mean $\pm \mathrm{SD}$ & $0.932^{\mathrm{a}}$ \\
\hline$\Delta$ Asupan $\mathrm{E}$ & $23.73 \pm 159.29$ & $17.11 \pm 228.24$ & $0.846^{\mathrm{a}}$ \\
$\Delta$ Asupan KH & $-0.69 \pm 22.88$ & $2.18 \pm 47.79$ & $0.379^{\mathrm{a}}$ \\
$\Delta$ Asupan L & $5.56 \pm 15.35$ & $1.26 \pm 7.70$ & $0.856^{\mathrm{a}}$ \\
$\Delta$ Asupan P & $-0.84 \pm 11.90$ & $-1.54 \pm 5.77$ & $0.762^{\mathrm{a}}$ \\
$\Delta$ Asupan & $-0.43 \pm 1.36$ & $-0.16 \pm 2.95$ & \\
serat & & & \\
\hline
\end{tabular}

Keterangan: $a=$ Independent $t$-test

Tabel 5 menunjukkan tidak ada perbedaan perubahan asupan energi, karbohidrat, lemak, protein, dan serat pada kelompok kontrol dan perlakuan $(p>0.05)$.

Daya terima Jus Lidah Buaya pada Kelompok Perlakuan

Selama penelitian kelompok perlakuan mendapatkan intervensi berupa jus lidah buaya sebanyak 150 gram. Terdapat satu orang subyek penelitian yang menyisakan jus lidah buaya sebanyak $25 \mathrm{ml}$ selama dua hari sehingga rerata asupan jus lidah buaya pada kelompok perlakuan adalah 149.58 gram per hari $(99.72 \%)$.

Perbedaan Kadar Glukosa Darah Setelah Intervensi

Pada kelompok kontrol diketahui tidak mengalami penurunan kadar GDP selama intervensi $(p>0.05)$, sedangkan pada kelompok perlakuan yang mendapatkan jus lidah buaya mengalami penurunan kadar GDP secara bermakna $(p<0.05)$. Data pengaruh konsumsi jus lidah buaya terhadap kadar GDP pada masingmasing kelompok dapat dilihat pada tabel 6 .

Tabel 6. Perbedaan Kadar Glukosa Darah Setelah Intervensi

\begin{tabular}{|c|c|c|c|c|c|c|}
\hline \multirow{2}{*}{ Pengukuran } & Perlakuan & \multirow{2}{*}{$\mathrm{p}$} & \multicolumn{3}{|c|}{ Kontrol } & \multirow[b]{2}{*}{$\mathrm{p}$} \\
\hline & Mean \pm SD & & Median & Min & $\operatorname{Max}$ & \\
\hline $\begin{array}{l}\text { GDP pre } \\
\text { GDP post }\end{array}$ & $\begin{array}{l}110.07 \pm 8.19 \\
89.69 \pm 12.31\end{array}$ & $0.001^{\mathrm{c}^{*}}$ & $\begin{array}{c}104.0 \\
106\end{array}$ & $\begin{array}{c}100 \\
94\end{array}$ & $\begin{array}{l}125 \\
130\end{array}$ & $0.824^{\mathrm{c}}$ \\
\hline
\end{tabular}

Keterangan: $p^{*}=$ beda bermakn, $c=$ Wilcoxon test

Perubahan Kadar Glukosa Darah Puasa antara Kelompok yang Diberi dan Tidak Diberi Jus Lidah Buaya
Terdapat perbedaan perubahan kadar GDP antara kelompok perlakuan dan kelompok kontrol. Perbedaan rerata perubahan GDP masing-masing kelompok dapat dilihat pada tabel 7.

Tabel 7. Perubahan Kadar Glukosa Darah Puasa antara Kelompok yang Diberi dan Tidak Diberi Jus Lidah Buaya

\begin{tabular}{cccc}
\hline \multirow{2}{*}{ Pengukuran } & Perlakuan $(\mathrm{n}=13)$ & Kontrol $(\mathrm{n}=13)$ & \multirow{2}{*}{$\mathrm{p}$} \\
\cline { 2 - 3 } \multicolumn{1}{c}{ Mean \pm SD } & Mean \pm SD & $0.001^{\mathrm{a}^{*}}$ \\
\hline Ketren & $20.38 \pm 14.7$ & $0.38 \pm 11.12$ &
\end{tabular}

Keterangan: $p^{*}=$ beda bermakna, $a=$ Independent $t$-test

PEMBAHASAN

penurunan kadar GDP sebesar $20.38 \mathrm{mg} / \mathrm{dl}$ atau Hasil penelitian yang dilakukan pada wanita sebesar $18.92 \%(p<0.05)$ sedangkan pada kelompok prediabetes diketahui bahwa rerata kadar GDPkontrol rerata penurunan kadar GDP sebesar 0.38 sebelum intervensi pada kelompok perlakuan adalah $\mathrm{mg} / \mathrm{dl} \quad(p>0.05)$. Uji statistik menunjukkan ada $110.07 \mathrm{mg} / \mathrm{dl}$ sedangkan pada kelompok kontrol perbedaan perubahan GDP antara kedua kelompok adalah $108.00 \mathrm{mg} / \mathrm{dl}$. Menurut Perkumpulan $(p<0.05)$. Kadar GDP dipengaruhi oleh beberapa Endokrinologi Indonesia kadar glukosa darah puasafaktor diantaranya adalah jenis kelamin, usia, indeks untuk kondisi prediabetes berkisar antara 100-125 massa tubuh, status menopause, aktivitas fisik, dan $\mathrm{mg} / \mathrm{dl}{ }^{4}$ Pada kelompok perlakuan memiliki rerata asupan. 
Sebaran usia 50-55 tahun (46.2\%) paling banyak ditemukan pada penelitian ini. Uji statistik menunjukkan ada perbedaan usia antara kelompok kontrol dan kelompok perlakuan $(p<0.05)$. Kelompok kontrol didominasi oleh kelompok usia 50-55 tahun (30.76\%) dan 45-49 tahun (19.23\%). Kadar glukosa darah puasa meningkat $1-2 \mathrm{mg} \%$ per tahun setelah mencapai usia 30 tahun. Resistensi insulin yang terjadi disebabkan oleh 4 faktor yaitu perubahan komposisi tubuh, penurunan aktivitas fisik, perubahan pola makan, dan penurunan sensitivitas insulin. ${ }^{9}$ Perbedaan sebaran usia mempengaruhi perbedaan perubahan kadar GDP antara kedua kelompok.

Subyek penelitian sebagian besar mengalami menopause (61.53\%). Wanita yang mengalami menopause akan mengalami penurunan kadar hormon estrogen yang cenderung akan meningkatkan kadar glukosa darah. ${ }^{10}$ Namun uji statistik yang dilakukan menunjukkan tidak terdapat perbedaan kadar GDP sebelum intervensi dan perbedaan perubahan kadar GDP antara kelompok menopause dan kelompok belum menopause $(p>0.05)$ sehingga status menopause bukan merupakan variabel perancu dalam penelitian ini.

Sebagian besar $(73.1 \%)$ subyek penelitian tergolong obesitas tingkat I. Uji statistik menunjukkan tidak ada perbedaan indeks massa tubuh pada kedua kelompok ( $p>0.05)$. Resistensi insulin pada penderita obesitas terjadi karena sel lemak viseral berperan menghasilkan sejumlah sitokin pro-inflamasi seperti TNF- $\alpha$, IL-1, dan IL-6 yang dapat mengganggu aksi normal insulin dalam sel lemak dan sel otot. Akumulasi lemak dalam hati juga menyebabkan peningkatan kadar asam lemak dalam darah dan peningkatan produksi glukosa hepatik sehingga meningkatkan risiko DM tipe II. ${ }^{11}$

Subyek penelitian seluruhnya bekerja sebagai ibu rumah tangga yang sebagian besar memilik aktivitas fisik sedang (80.08\%). Uji statistik menunjukkan tidak ada perbedaan tingkat aktivitas fisik pada kedua kelompok $(p>0.05)$. Aktivitas fisik yang rendah merupakan faktor independen terjadinya prediabetes dan DM tipe II. Aktivitas fisik dapat memperbaiki kadar glukosa darah secara menyeluruh dengan meningkatkan respon membran sel terhadap glukosa dan sensitivitas sel terhadap insulin. ${ }^{12}$

Salah satu cara untuk meningkatkan aktivitas fisik adalah dengan melakukan olah raga teratur. Sebanyak $15.3 \%$ subyek penelitian mempunyai kebiasaan olahraga bersepeda setiap hari selama 30 menit dan $19.2 \%$ mempunyai kebiasaan olahraga senam jantung sehat semingu sekali selama 30 menit. Olahraga secara intensif selama 2,5 jam perminggu diketahui dapat mencegah timbulnya gangguan toleransi glukosa atau prediabetes dan DM tipe II. ${ }^{13}$

Rerata asupan energi sebelum $(1804.3 \pm 246.2 \mathrm{kkal})$ dan setelah intervensi $(1780.6 \pm 185 \mathrm{kkal})$ pada kelompok perlakuan diketahui lebih tinggi dari asupan energi sebelum $(1679.8 \pm 237.5 \mathrm{kkal})$ dan setelah intervensi (1662.2 $\pm 234.7 \mathrm{kkal})$ pada kelompok kontrol. Hal ini dikarenakan kelompok perlakuan memiliki rerata asupan lemak sebelum (75.9 \pm 13.6$)$ dan setelah intervensi $(60.9 \pm 10.2)$ lebih tinggi dari rerata asupan lemak sebelum $(70.4 \pm 9.6)$ dan setelah intervensi $(59.6 \pm 12.3)$ pada kelompok kontrol. Uji statistik menunjukkan perbedaan asupan lemak secara bermakna antara kedua kelompok $(p<0.05)$. Berdasarkan hasil data food record kelompok perlakuan diketahui lebih sering mengonsumsi makanan yang diolah dengan cara digoreng dan lebih sering mengonsumsi sumber lemak dari lauk hewani.

Uji statistik menunjukkan tidak terdapat perbedaan perubahan asupan energi dan lemak antara kedua kelompok $(p>0.05)$. Namun rerata penurunan asupan energi dan lemak selama penelitian pada kelompok perlakuan lebih besar dibanding kelompok kontrol. Hal ini dikarenakan subyek penelitian pada kelompok perlakuan mengubah pola makan seperti mengurangi porsi makan, mengurangi konsumsi gorengan, minuman dan makanan manis, menghilangkan waktu makan utama serta meningkatkan konsumsi buah dan sayur. Konsumsi makanan rendah kalori, rendah lemak dan tinggi serat dapat membantu mengendalikan kadar glukosa darah. ${ }^{4}$

Rerata asupan karbohidrat sebelum intervensi kelompok perlakuan (234.8 \pm 35.8 gram) lebih tinggi dibanding kelompok kontrol $(238.1 \pm 36$ gram). Rerata asupan karbohidrat selama intervensi kelompok perlakuan $(240.3 \pm 33)$ juga lebih tinggi dari pada kelompok kontrol (235.5 \pm 30.8 gram). Meskipun uji statistik menunjukkan tidak terdapat perbedaan perubahan asupan karbohidrat antara kelompok kontrol dan perlakuan $(p>0.05)$, pada kelompok perlakuan diketahui mengalami peningkatan asupan karbohidrat. Ketika subyek penelitian menghilangkan waktu makan atau mengurangi porsi nasi mereka menggantinya dengan mengonsumsi makanan selingan berupa roti dan umbi-umbian. 
Makanan sumber karbohidrat akan dicerna dan diabsorbsi dengan kecepatan yang berbedabeda sehingga karbohidrat dengan jumlah berbeda tidak memberikan efek yang sama terhadap kadar glukosa darah, produksi insulin, maupun kadar lipid darah. Karbohidrat yang memiliki indeks glikemik (IG) tinggi 70-100 dan beban glikemik tinggi >20 dapat memicu sekresi insulin secara cepat. ${ }^{14}$ Nasi memiliki IG antara 54-84 dengan beban glikemik 30, sedangkan roti basah memiliki IG 35-41 dengan beban glikemik 20, ubi jalar memiliki IG 44 dengan beban glikemik 11 dan singkong memiliki IG 46 dengan beban glikemik 12. Pemilihan jenis makanan yang dilakukan subyek penelitian pada kelompok perlakuan dengan memilih makanan sumber IG dan beban glikemik yang rendah juga dapat membantu mengendalikan kadar glukosa darah dan menurunkan kadar asam lemak bebas dalam darah. $^{15}$

Uji statistik menunjukkan tidak ada perbedaan perubahan asupan serat sebelum dan selama penelitian pada kelompok kontrol dan perlakuan $(p>0.05)$. Namun uji hubungan antara perubahan kadar GDP dengan perubahan asupan serat pada kelompok perlakuan menunjukan adanya hubungan secara bermakna $(p<0.05)$, dengan besar pengaruh kuat $(r=0.636)$. Asupan serat dalam jumlah yang cukup dapat memberikan manfaat metabolik pada pengendalian glukosa darah, hiperinsulinemia, dan kadar lipid plasma. ${ }^{4}$ Kelompok perlakuan diketahui mengalami peningkatan asupan serat selama penelitian dari sayur, buah dan jus lidah buaya. Kandungan $A$. vera $99 \%$ berupa air dan sisanya adalah padatan berupa monosakarida dan polisakarida. Kurang lebih $5-10 \%$ dari padatan polisakarida berupa heksosa dan 20\% berupa acemannan, glucomannan dan serat. ${ }^{16}$ Meskipun kandungan serat, acemannan dan glucomannan pada A. vera kecil tetapi konsumsi $A$. vera dalam jangka waktu 14 hari dan dosis 150 gram dapat membantu mengontrol kadar glukosa darah puasa.

Glucomannan adalah serat larut air yang berperan dalam memperbaiki sensitivitas insulin dan menurunkan kebutuhan insulin dengan membantu insulinisasi jaringan lebih efektif sehingga tidak terjadi peningkatan kadar glukosa darah secara signifikan. Sama seperti serat larut air lainnya, glucomannan akan meningkatkan viscositas lambung sehingga menurunkan laju penyerapan glukosa, menyebabkan perubahan level hormon di saluran cerna seperti gastric inhibitory polipeptida (GIP), glukagon, dan somatostatin yang berpengaruh pada motilitas saluran pencernaan, penyerapan zat gizi, dan sekresi insulin. ${ }^{13}$

Acemannan (ß- $(1,4)-$ linked acetylated mannan) merupakan karbohidrat utama di dalam lidah buaya yang sebagian besar kandungannya adalah mannose yang dapat digunakan sebagai terapi hipoglikemik. ${ }^{6}$ Pada penelitian sebelumnya menyebutkan bahwa acemannan memiliki efek sebagai antioksidan. ${ }^{17}$ Menurut uji yang dilakukan di Laboratorium Universitas Soegijapranato, jus lidah buaya memiliki aktivitas antioksidan sebesar 2.259\%. Penelitian pada tikus putih (Rattus norvegicus) hiperglikemik yang diberi ekstrak etanol gel $A$. vera dengan dosis 100 dan 500 $\mathrm{mg} / \mathrm{kgBB}$ tikus selama 6 hari diketahui mengalami penurunan kadar glukosa darah puasa sebesar 7,1\% dan $12 \%{ }^{8}$

Pada keadaan hiperglikemi, glukosa akan mengalami reaksi glikosilasi nonenzimatik secara spontan dengan hemoglobin membentuk glycated hemoglobin. Glukosa dapat teroksidasi sebelum berikatan dengan hemoglobin demikian juga glukosa setelah berikatan dengan hemoglobin akan teroksidasi dan menghasilkan Reactive Oxygen Spesies (ROS). ROS akan meningkatkan pembentukan ekspresi Tumor necrosis factor $\alpha$ $(\mathrm{TNF} \alpha)$ yang mengakibatkan resistensi insulin melalui penurunan autofosforilasi dari reseptor insulin, perubahan reseptor insulin substrat (IR-s) menjadi inhibitor receptor tyrosine kinase activity, penurunan insuline-sensitive glucose transporter (GLUT-4), merubah fungsi sel $\beta$, dan meningkatkan sirkulasi asam lemak. ${ }^{18}$ Aktivitas antioksidan ekstrak $A$. vera meningkatkan toleransi glukosa dengan cara mencegah oksidasi glukosa darah, menurunkan potensi enzim-enzim yang berperan dalam pemindahan gugus fosfat pada glukosa yang merupakan tahap awal proses glikosilasi dan memperbaiki stress oksidatif. ${ }^{8}$

Penelitian lain menyebutkan bahwa $A$. vera dapat berperan dalam menurunkan kadar glukosa darah dan meningkatkan glikogen hati yaitu dengan meningkatkan aktivitas sel $\beta$ pankreas dalam menstimulasi biosintesis dan sekresi insulin. ${ }^{7} A$. vera juga membantu memperbaiki toleransi glukosa dengan menurunkan glukosa-6fosfat dan fruktosa-1,6-bifosfat serta meningkatkan hexokinase sehingga menghambat produksi glukosa yang berasal dari hepar dan meningkatkan ambilan glukosa oleh otot. ${ }^{19}$

Pada kelompok kontrol subyek penelitian memiliki rerata usia lebih tua, IMT lebih tinggi, dan status menopause lebih banyak dibandingkan 
kelompok perlakuan. Keadaan tersebut memperberat keadaan prediabetes sehingga berpengaruh terhadap perubahan kadar glukosa darah puasa setelah intervensi. Keadaan prediabetes dapat diperbaiki dengan merubah gaya hidup, menurunkan berat badan, mengkonsumsi diet sehat, dan melakukan olahraga secara teratur. ${ }^{4}$

\section{KETERBATASAN PENELITIAN}

Keterbatasan penelitian ini adalah tidak dilakukan uji kandungan serat pangan khususnya acemannan dan glucomannan pada lidah buaya.

\section{SIMPULAN}

Terdapat penurunan kadar glukosa darah puasa sebesar $20.38 \mathrm{mg} / \mathrm{dl}$ setelah pemberian jus lidah buaya sebanyak 150 gram selama 14 hari.

\section{SARAN}

1. Diperlukan uji laboratorium untuk mengetahui besar kandungan polisakarida acemannan dan glucomanan di dalam lidah buaya.

2. Penderita prediabetes dianjurkan untuk mengkonsumsi jus lidah buaya karena dapat membantu mengontrol kestabilan glukosa darah.

\section{DAFTAR PUSTAKA}

1. Manaf A. Insulin : Mekanisme sekresi dan aspek metabolisme. Dalam : Buku ajar ilmu penyakit dalam jilid III edisi 4. Jakarta : Pusat Penerbit Departemen Ilmu Penyakit Dalam Fakultas Kedokteran Universitas Indonesia; 2006. Hal 186869.

2. Kementrian Kesehatan. Petunjuk teknis pengukuran faktor risiko diabetes mellitus. Kementrian Kesehatan RI; 2008.

3. Dinas Kesehatan Kota Semarang. Profil kesehatan Kota Semarang 2010. Semarang : Dinas Kesehatan Kota Semarang; 2010.

4. Perkumpulan Endokrinologi Indonesia. Konsensus pengelolaan dan pencegahan diabetes mellitus Tipe 2 di Indonesia. Jakarta : PB. PERKENI; 2006. Hal 3-14, 30-31.

5. Soewondo P, Laurentinus AP. Prevalensi, characteristics, and predictor of pre-diabetes in Indonesia. Departement of Internal Medicine Faculty of Medicine Universitas Indonesia 2011; 20: $283-293$

6. Steencamp V, Stewart MJ. Medicinal application and toxicological activities of Aloe product. Forensic Pathology Research 2007; 27:773-5.

7. Helal EGE, Mohamad HAH, Ashraf MM and Anwaar A. Effect of A. vera extract on some physiological parameters in diabetic albino rats.
The Egyptian Journal of Hospital Medicine 2003; $12: 53-61$.

8. Afaf, Abuelgasim I, Maha KMO and Elmahdi B. Effect of A. vera (Elsabar) ethanolic extract on blood glucose level in Wistar albino rats. Journal of Applied Science Research 2008; 4(12):1841-1845.

9. Rochmah W. Diabetes mellitus pada usia lanjut. Dalam: Sudoyo AW, Setiyohadi B, Alwi I, Simadibrata M, Setiati S, editors. Buku ajar ilmu penyakit dalam. 4th ed. Jakarta: Pusat Penerbitan IPD FKUI; 2007.p.1915-18.

10. Deanna G. Women's monthly cycle affects blood glucose control, but not consistently, diabetes health; 2009. Available from: http://www.diabeteshealth.com [Accessed 18 February 2010].

11. Mlinar B, Marc J, Janez A, Pfeifer M. Molekuler mekanisme resistensi insulin dan penyakit yang terkait. Clinica Chimica Acta 375 (2007) 20-35

12. Pemayun TGD. Indeks Glikemik: Kontroversi dalam penanganan DM. Dalam: Diabetes mellitus ditinjau dari berbagai aspek penyakit dalam. Semarang : Badan Penerbit UNDIP (PERKENI); 2007. Hal 133-154.

13. Bender DA. Nutrition and metabolism $4^{\text {th }}$ edition. CRP Press. Hal 83-86.

14. Siagian RA. Indeks glikemik pangan. Jakarta: Penebar Swadaya; 2004: 107-112.

15. Saed MA, Istiaq A, Uzma Y, Shazin A, Amran W, M Salem, et.al. A. vera: A plant of vital significance. Department of Botany, Govt. College, Lahore. Quarterly Science Vision; 2003: Vol 9: 1-5

16. Yun $H$, Juan $X$, Qiuhui $H$. Evaluation of antioxidant potential of A. vera (Aloe Barbadensis Miller) extracts. Journal of Agricultural and Food Chemistry. Department of Biology, Changsu College of Science and Technology. Changsu: 2003 [cited 5 Agustus 2011] Available from: http:// www.sld.cu/galerias/

pdf/sitios/mednat/actividad_antioxidante_aloe_vera .pdf

17. Widowati W. potensi antioksidan sebagai antidiabetes. Bandung: Fakultas Kedoketeran Universitas Kristen Maranata. 2008; (7): 193-202.

18. Rajasekaran S, D Sathishsekar. Therapeutic evaluation of A. vera leaf gel extrac on glycoprotein components in rats with streptozotocin Diabetes. Journal of Pharmacology and Toxicologi; 2007:2(4):380-385.

19. Rajasekaran S, Sivagnanam K, Subramanian S. Antioxidant effect of $A$. vera leaf gel extract in streptozotocin diabetes in rats. Paharmacol; 2005. Rep. 57:90-6. 